\title{
Evaluation of phytochemical contents and physiological activity in Panax ginseng sprout during low-temperature aging
}

\author{
A-Ro Cho, Min-Jung Pyo, Min-Jung Kang, Jung-Hye Shin* \\ Namhae Garlic Research Institute, Namhae 52430, Korea
}

저온숙성 과정 중 새싹인삼의 이화학적 특성변화

\author{
조아로·표민정 · 강민정 · 신정혜* \\ (재) 남해마늘연구소
}

\begin{abstract}
To investigate the phytochemical componetns and physiological activity of Panax ginseng sprout (PGS) during low-temperature aging, sprouts were aged at 40 and $60^{\circ} \mathrm{C}$ for $0.5,1,2,3$, and 4 days. The crude saponin content in PGS aged at $60^{\circ} \mathrm{C}$ was found to be higher at an early aging time. However, with aging, the content at $40^{\circ} \mathrm{C}$, increased rapidly, and become significantly higher in the PGS aged at $60^{\circ} \mathrm{C}$. The total content of phenolic compounds gradually increased with aging, with the highest content being 341.3 gallic acid equivalent (GAE) $\mathrm{mg} / 100 \mathrm{~g}$ on day 4 at $40^{\circ} \mathrm{C}$ and $431.5 \mathrm{GAE} \mathrm{mg} / 100 \mathrm{~g}$ on day 3 at $60^{\circ} \mathrm{C}$. Among the ginsenosides, the Re, Rb1, and Rg1 contents were higher and the total content was higher at the early aging time in sprouts aged at $60^{\circ} \mathrm{C}$, however, there were no significant differences in the contents on day 4. The 2,2-diphenyl-1-picrylhydrazyl and 2,2'-azino-bis(3-ethylbenzothiazoline-6-sulfonic acid) (ABTS) radical scavenging activities increased with aging of PGS. The ABTS activities in PGS aged at $40^{\circ} \mathrm{C}$ and $60^{\circ} \mathrm{C}$ were highest on day 3 and 2, respectively. Thus, the ginsenoside content and physiological activity of the PGS increased throughout the aging process. The optimal aging temperature and time were 3 days at $40^{\circ} \mathrm{C}$ and 2 days at $60^{\circ} \mathrm{C}$.
\end{abstract}

Key words : Panax ginseng sprout, aging, ginsenosides, phenolic compounds, radical scavenging activity

\section{서 론}

인삼(Panax ginseng C.A. Meyer)은 두릅나무과에 속하는 다년생 초본으로 $\operatorname{Panax}$ 의 어원에서 $\operatorname{Pan}$ 은 모든 것을 의미 하며 Axos는 치료를 의미하여 다양한 약리작용을 나타내어 다방면으로 사용되는 만병통치의 의미를 지니고 있다 $(1,2)$ 한방에서 인삼은 주로 원기회복에 사용되는 가장 중요한 보약으로 알려져 있으며, 중국과 우리나라의 한방의서에 수록되어 자양강장, 피로회복, 면역력 증진, 소화기계, 신경 계, 순환기계 등의 기능조절을 위해 활용된다고 알려져 있

*Corresponding author. E-mail : whanbee@daum.net Phone : 82-55-860-8947, Fax : 82-55-860-8960

Received 27 September 2018; Revised 26 December 2018; Accepted 27 December 2018.

Copyright (c) The Korean Society of Food Preservation. All rights reserved.
다(3)

인삼은 뿌리를 취하여 주로 약용으로 사용해 왔는데, 인 삼의 뿌리에 존재하는 사포닌, 폴리아세틸렌, 폴리페놀물 질 및 산성당 등은 약리작용에 효능이 있는 성분으로 이들 중 사포닌 성분이 가장 중요한 약리작용 효능 물질로 알려 져 있다(4). 대표적인 사포닌의 약리효능으로는 중추신경 계 및 뇌기능의 향상, 항암, 항산화, 심혈관 장애개선, 면역 증진 및 항당뇨 등이 있다(5). 인삼뿌리에서 주로 분리된 사포닌은 38 여 종 인데, 진세노사이드 $\mathrm{Rb} 1, \mathrm{Rb} 2, \mathrm{Re}$, 및 $\mathrm{Rg} 1$ 이 총 진세노사이드 함량의 $80 \%$ 이상을 차지하며 이러 한 사포닌들을 경구 투여 할 경우 혈관을 이완시켜 항 피로 및 혈압 강하작용에 기여하는 등의 효능을 보인다 $(6,7)$. 이 외에도 인삼의 유효성분과 관련하여 수삼 증숙 횟수에 따른 페놀산의 함량 변화와 라디칼 소거활성(8), 유기산 처리에 따른 홍삼추출물의 페놀성물질 변화(9), 백삼 내 페놀산 조성과 항산화활성(10) 등 인삼의 가공과 유효물질의 변화 
와 관련한 연구들이 진행되어 있다. 최근 들어 인삼 뿌리 못지않게 잎에도 유효성분이 다양하게 함유되어 있다고 보고되어 $(11,12)$ 인삼 잎에 대한 관심이 높아지고 있으며 발효처리 한 인삼 잎의 진세노사이드 및 페놀산 조성변화와 생리활성에 미치는 영향(13), 수경재배 인삼 잎 첨가 개성주 악의 항산화활성 및 품질 특성(14) 등의 연구처럼 인삼 잎을 활용하고자 하는 연구도 활발히 진행되고 있다.

인삼은 옛부터 연구되어 가공형태가 다양하게 발달하여 왔으며, 가공형태에 따라 가치가 증가하는 경향이 있어 최 근 소비자의 기호를 만족시키기 위해 여러 방면으로 인삼제 품이 가공, 개발되고 있다(15). 하지만 인삼의 재배 방식에 서는 연작에 따른 각종 병충, 병해를 막기 위해 사용한 농약 과 그 잔류, 토양의 질 변화에 따른 문제점 및 3-6년간의 긴 재배기간은 인삼 재배의 한계점으로 지적되고 있다(16).

이러한 인삼의 단점을 보완하고자 개발된 새싹인삼 (Panax ginseng sprout)은 인삼 종자로부터 싹을 틔워 24개 월 미만인 묘삼을 29-40일 정도 수경 또는 토경재배를 통해 수확한 인삼의 뿌리와 어린잎 전체를 의미하는데, 상대적 으로 재배 기간이 짧고 잎, 줄기까지 모두를 섭취하는 특성 을 가진다(17). 또, 인삼과 비교하여 새싹인삼은 계절에 제 한을 받지 않아 연중재배가 가능하고 연작이 가능한 $(16,18)$ 재배의 장점이 있고 새싹인삼 잎에는 간 기능보호, 피로회 복 기능 등을 가진 진세노사이드 $\operatorname{Rg} 1$ 이 $65 \%$ 이상을 차지하 며, 뿌리보다 진세노사이드 함량이 3배 이상 높아 영양적으 로 가치가 높다(18). 이러한 새싹인삼은 샐러드, 주스 등으 로 섭취되므로 주로 생으로 유통이 되고 있으나 최근에는 활용도를 높이고자 가공품 개발에 관한 연구들이 진행되고 있는데, 새싹인삼을 첨가한 고부가가치 수산가공품의 제조 (17), 새싹인삼을 첨가한 카스텔라(19), 굴과 새우를 이용한 새싹삼 페이스트(20) 등이 연구되어 있다. 하지만 아직까지 새싹인삼을 다양하게 가공할 수 있는 전처리 기술의 개발이 나 이에 따른 유효성분의 변화, 여러 가공품에 적용을 위한 연구 등 관련한 연구들은 부족한 실정이다.

본 연구에서는 새싹인삼의 성분과 생리 활성을 향상시킬 수 있는 가공 방법 모색을 위한 연구의 일환으로 전처리를 거친 새싹인삼을 온도를 달리하여 숙성시키면서 유효성분 및 생리활성의 변화를 분석하였다.

\section{재료 및 방법}

\footnotetext{
시료의 제조

흐르는 물에서 충분히 세척한 새싹인삼을 3 시간 정도 풍건하여 수분을 제거한 다음 길이 2-3 cm 정도로 절단하여 부직포에 가볍게 싸서 10 분간 손으로 가볍게 비벼 유념 처리하였다. 유념 처리된 새싹인삼은 한지로 3 겹으로 포장 하여 $40^{\circ} \mathrm{C}$ 와 $60^{\circ} \mathrm{C}$ 항온항습기(JSTH-150CPL, JSR research
}

Co., Gongju, Korea)에서 각각을 숙성하였다. 숙성 12시간 (0.5일), $1,2,3$ 일에 각각 시료를 취하여 전체를 분쇄한 후 실험용 시료로 사용하였으며, 활성검증을 위한 추출물은 시료 무게 대비 10 배의 물을 가하여 3 시간 동안 상온에서 초단파 추출한 다음 여과지(Whatman No.2)로 여과한 여액 을 사용하였다.

\section{수분, 갈변도 및 가용성 고형분}

수분은 시료 $1 \mathrm{~g}$ 을 취하여 자동수분측정기(MB45, Ohaus, Zürich, Switzerland)로 3회 반복 측정하였다. 갈변도는 각 시료의 추출여액을 spectrophotometer(Libra S35, Biochrome Ltd., Cambridge, England)로 $280 \mathrm{~nm}$ 와 $420 \mathrm{~nm}$ 에서 3회 반복 측정하였으며, 가용성 고형분은 여과한 시료액을 일정량 취하여 자동굴절당도계(PR-201 a, Atago Co, Tokyo, Japan) 로 3 회 반복 측정하였다.

\section{조사포닌}

숙성하여 분쇄한 새싹인삼 $5 \mathrm{~g}$ 을 증류수 $30 \mathrm{~mL}$ 에 용해시 킨 후 ethyl ether $50 \mathrm{~mL}$ 로 씻은 다음 증류수층을 회수하여 butanol $50 \mathrm{~mL}$ 로 3회 추출하였다. 미리 항량을 구한 농축플 라스크에 추출액을 옮겨 감압 농축하여 butanol을 제거한 후 $70^{\circ} \mathrm{C}$ 에서 건조하여 항량을 구하였다. 조사포닌 함량은 butanol 층을 농축 건조한 후의 플라스크 무게 $(\mathrm{mg})$ 에서 빈 플라스크의 무게 $(\mathrm{mg})$ 를 뺀 값을 시료채취량 $(\mathrm{g})$ 으로 나누어 산출하였다.

\section{총 페놀화합물}

Folin-Denis 법(21)에 따라 시료 추출 여액 $1 \mathrm{~mL}$ 에 Foline-Ciocalteu(Sigma-Aldrich Co., St. Louis, MO, USA) 시약 $0.5 \mathrm{~mL}$ 를 넣고 3분간 충분히 교반한 다음 $10 \% \mathrm{Na}_{2} \mathrm{CO}_{3}$ 용액을 $0.5 \mathrm{~mL}$ 가하여 실온의 암실에서 1 시간 정치한 후 $760 \mathrm{~nm}$ 에서 흡광도를 측정하였다. 표준물질로 gallic acid(Sigma-Aldrich Co.)를 사용하여 시료와 동일한 방법으 로 분석하여 얻은 검량선으로 부터 총 페놀화합물의 함량을 계산하여 gallic acid equivalent(mg GAE/g)로 표기하였다.

\section{클로로필}

분쇄한 시료 $5 \mathrm{~g}$ 에 $80 \%$ 아세톤을 가해 $50 \mathrm{~mL}$ 로 만들어 진탕 교반하여 추출 한 후 여과한 여액을 시료로 하여 spectrophotometer(Libra S35, Biochrome Ltd., Cambridge, England)로 $645 \mathrm{~nm}$ 와 $663 \mathrm{~nm}$ 에서 흡광도를 측정한 다음 아래의 계산식에 의해 함량을 산출하였다.

$$
\begin{aligned}
& \text { Chlorophyll } \mathrm{a}(\mathrm{mg} / \mathrm{L})=12.72 \times \mathrm{OD}_{663}-2.58 \times \mathrm{OD}_{645} \\
& \text { Chlorophyll } \mathrm{b}(\mathrm{mg} / \mathrm{L})=22.88 \times \mathrm{OD}_{645}-5.50 \times \mathrm{OD}_{663} \\
& \text { Total chlorophyll }(\mathrm{mg} / \mathrm{L})=7.22 \times \mathrm{OD}_{663}+20.3 \times \mathrm{OD}_{645}
\end{aligned}
$$




\section{진세노사이드}

시료 $3 \mathrm{~g}$ 을 $50 \mathrm{~mL}$ conical tube에 넣고 $30 \mathrm{~mL}$ 의 $50 \%$ $\mathrm{MeOH}$ 을 첨가한 후 15 분 동안 초음파 추출하여 여과하였 다. Sep-Pak Plus $\mathrm{C}_{18}$ cartridge(Waters, Milford, MA, USA)에 $3 \mathrm{~mL} \mathrm{MeOH}$ 를 서서히 용출시킨 다음 $3 \mathrm{~mL}$ 증류수로 2차 용출 시켰다. 추출 시료액 $2 \mathrm{~mL}$ 을 cartridge에 통과시키고 $10 \mathrm{~mL}$ 증류수로 서서히 용출하여 당류 등을 제거하였다. 이 cartridge에 $\mathrm{MeOH} 2 \mathrm{~mL}$ 를 가하여 진세노사이드 성분을 용출한 후 $0.45 \mu \mathrm{m}$ membrane filter로 여과하였다. 진세노사 이드 함량은 HPLC-DAD(Agilent 1260, Agilent Technologies, Santa clara, CA, USA)로 분석하였다. 분석 컬럼은 Agilent Zorbax SB-C ${ }_{18}(4.6 \times 250 \mathrm{~mm}, 5 \mu \mathrm{m}$, Agilent Technologies)를 사용하였고, 컬럼 온도 $40^{\circ} \mathrm{C}, \mathrm{UV}$ 검출기의 검출파장 203 $\mathrm{nm}$ 로 조정하여 70 분간 분석하였다. 이동상은 $\operatorname{water}(\mathrm{A})$ 와 acetonitrile(B)를 사용하여 용매 $\mathrm{A}: \mathrm{B}$ 를 7:3(0분), 6:4(30분), $5: 5$ (30분), $1: 9$ (50분), $5: 5$ (70분)의 조건으로 변화시키면서 유속 $0.8 \mathrm{~mL} / \mathrm{min}$ 로 조정하였다. 표준물질로 10 종 $(\mathrm{Re}, \mathrm{Rg} 1$, $\mathrm{Rf}, \mathrm{Rb} 1, \mathrm{Rg} 2, \mathrm{Rh} 1, \mathrm{Rb} 2, \mathrm{Rd}, \mathrm{Rg} 3, \mathrm{Rh} 2$ )의 진세노사이드 (Sigma-Aldrich Co.)를 사용하여 시료와 동일한 방법으로 분석하여 얻은 검량선으로 부터 함량을 계산하였다.

\section{항산화활성}

새싹인삼 효소분해 액의 항산화활성은 1,1-diphenyl-2picrylhydrazyl(DPPH)와 2,2'-azino-bis(3-ethylbenzothiazoline6-sulphonic acid)(ABTS) 라디칼 소거활성을 통해 평가하였 다. DPPH 라디칼 소거활성은 $\mathrm{DPPH}$ 에 대한 전자공여 활성 으로 나타낸 것으로 시료의 항산화활성이 높을수록 보라색 의 시약이 탈색 되는 원리를 이용한다. Blois(22)의 방법을 변형하여 $\mathrm{EtOH}$ 로 $1.5 \times 10^{-4} \mathrm{M}$ 농도가 되도록 조절한 $\mathrm{DPPH}$ 용액 $100 \mu \mathrm{L}$ 와 시료 $100 \mu \mathrm{L}$ 를 혼합한 다음 실온에서 20 분간 반응시킨 후 분광광도계를 이용해 $525 \mathrm{~nm}$ 에서 흡광도를 측정하여 시료 무첨가구에 대한 시료첨가구의 흡광도비로 계산하여 \%로 나타내었다.

$\mathrm{ABTS}$ 라디칼 소거능은 $\operatorname{Re}$ 등(23)의 방법에 따라 $7 \mathrm{mM}$ ABTS 용액에 potassium persulfate를 $2.4 \mathrm{mM}$ 이 되도록 용해 시킨 다음 암실에서 12-16시간 동안 반응시킨 후 $415 \mathrm{~nm}$ 에 서 흡광도가 1.5 가 되도록 증류수로 희석하였다. 이 용액 $100 \mu \mathrm{L}$ 에 농도별 시료액을 $100 \mu \mathrm{L}$ 를 가하여 실온에서 5 분 간 반응시킨 후 $415 \mathrm{~nm}$ 에서 흡광도를 측정하였으며, $\mathrm{ABTS}$ 라디칼 소거능은 시료첨가구와 무첨가구의 흡광도 비로 나타내었다.

\section{콜레스테롤 흡착활성}

콜레스테롤 흡착활성은 Soh 등(24)의 방법을 응용하여 kit시약(AM 202-k, Asan Pharm., Seoul, Korea)으로 측정하 였다. 시료액 $1 \mathrm{~mL}$ 에 콜레스테롤 $(300 \mathrm{mg} / \mathrm{dL}) 50 \mu \mathrm{L}$ 를 가하 여 $25^{\circ} \mathrm{C}$ 에서 20 분간 반응시킨 후 $0.1 \mathrm{M}$ hexadecyl- trimethylammonium bromide(Sigma-Aldrich Co.) $50 \mu \mathrm{L}$ 를 첨 가하여 $25,000 \times g$ 에서 15 분간 원심분리 시켰다. 상층액 200 $\mu \mathrm{L}$ 를 취하여 효소액 $1.5 \mathrm{~mL}$ 을 가해 혼합한 후 $37^{\circ} \mathrm{C}$ 에서 5 분간 반응시킨 다음 $500 \mathrm{~nm}$ 에서 흡광도를 측정하였으며, 시료 무첨가구에 대한 시료 첨가군의 흡광도 비로써 콜레스 테롤 흡착활성(\%)을 나타내었다.

\section{Angiotensin converting enzyme(ACE) 저해활성}

$\mathrm{ACE}$ 저해활성 측정은 Cushman와 Cheung(25)의 방법을 변형하여 측정하였다. 즉, $\mathrm{ACE}$ 저해활성은 $0.3 \mathrm{M} \mathrm{NaCl}$ 을 함유한 0.1 M sodium borate buffer(pH 8.3)에 rabbit lung acetone powder(Sigma-Aldrich Co.)를 $1 \mathrm{~g} / 10 \mathrm{~mL}(\mathrm{w} / \mathrm{v})$ 의 농 도로 $4^{\circ} \mathrm{C}$ 에서 24 시간 동안 추출한 후, $4^{\circ} \mathrm{C}, 4,000 \mathrm{rpm}$ 에서 40 분간 원심 분리하여 $\mathrm{ACE}$ 조효소액을 얻었다. $\mathrm{ACE}$ 저해 활성은 시료 $100 \mu \mathrm{L}$ 에 $0.1 \mathrm{M}$ sodium borate buffer( $\mathrm{pH}$ 8.3) $100 \mu \mathrm{L}$ 와 $\mathrm{ACE}$ 조효소액 $50 \mu \mathrm{L}$ 를 가한 다음 $37^{\circ} \mathrm{C}$ 에서 5 분간 예비반응 시킨 후, $0.3 \mathrm{M} \mathrm{NaCl}$ 이 함유된 $0.1 \mathrm{M}$ sodium borate buffer(pH 8.3) $5 \mathrm{~mL}$ 에 N-hippuryl-his-leu hydrate powder(Sigma-Aldrich Co.) $25 \mathrm{mg}$ 을 첨가하여 만든 기질 $50 \mu \mathrm{L}$ 를 첨가하여 $37^{\circ} \mathrm{C}$ 에서 30 분간 반응시켰다. 이에 1 $\mathrm{N} \mathrm{HCl} 250 \mu \mathrm{L}$ 를 가하여 반응을 정지시킨 후, ethyl acetate $1.5 \mathrm{~mL}$ 를 가해 15 초간 교반한 후 원심 분리 $(3,000 \mathrm{rpm} / 5$ $\min , 4^{\circ} \mathrm{C}$ )하여 상등액 $1 \mathrm{~mL}$ 를 얻었다. 이 상등액을 $120^{\circ} \mathrm{C}$ 에 서 30 분간 완전히 건조시켜 증류수 $3 \mathrm{~mL}$ 를 넣은 후에 228 $\mathrm{nm}$ 에서 흡광도를 측정하여 $\mathrm{ACE}$ 저해활성을 측정 하였다. 시료 무첨가군은 추출물 대신 추출용매 $100 \mu \mathrm{L}$ 를 가해 실험 하였으며, $\mathrm{ACE}$ 저해활성 효과는 다음 계산식을 이용하여 계산하였다.

ACE inhibition(\%)=1- $\frac{\text { sample absorbance-absorbance of sample blank }}{\text { control absorbance-absorbance of control blank }} \times 100$

\section{통계처리}

모든 실험은 3 회 이상 반복하여 실시하였으며 실험으로 부터 얻은 결과는 SPSS 18.0(IBM Corporation, Endicott, $\mathrm{NY}, \mathrm{USA})$ 을 사용하여 분석하였다. 결과치는 실험군당 평 균표준편차로 표시하였고, 통계적 유의성 검정은 일원배 치 분산분석 한 후 $\mathrm{p}<0.05$ 수준에서 Duncan's multiple range test를 시행하였다.

\section{결과 및 고찰}

\section{수분 및 갈변도}

숙성 온도를 달리한 새싹인삼의 숙성 기간에 따른 수분 변화와 갈변도를 분석한 결과는 Table 1 과 같다. 숙성 12 시 간에 $40^{\circ} \mathrm{C}$ 와 $60^{\circ} \mathrm{C}$ 숙성 시 수분은 각각 $80.12 \%$ 와 $74.65 \%$ 였 
고, 숙성 기간이 경과하면서 유의적으로 감소하였는데 숙 성 온도에 따라 수분의 감소 경향이 상이하였다. 즉, $40^{\circ} \mathrm{C}$ 숙성 시료의 경우 숙성 2 일에 수분 함량은 $67.72 \%$ 였는데, 숙성 3 일과 4 일에 급격히 감소하여 각각 $28.81 \%$ 와 $3.80 \%$ 였 다. 반면 $60^{\circ} \mathrm{C}$ 숙성 시료의 경우 숙성 1 일 후에 수분은 $55.69 \%$ 로 감소하였고, 숙성 2 일에는 $9.84 \%$ 로 급격히 감소 한 후 지속적으로 수분이 감소하여 숙성 최종일에 수분은 $1.54 \%$ 였다.

Table 1. Moisture content and browning intensity of aged Panax ginseng sprout with different temperature

\begin{tabular}{ccccc}
\hline $\begin{array}{c}\text { Aging } \\
\text { temperature } \\
\left({ }^{\circ} \mathrm{C}\right)\end{array}$ & $\begin{array}{c}\text { Aging } \\
\text { time } \\
(\text { days })\end{array}$ & $\begin{array}{c}\text { Moisture content } \\
(\%)\end{array}$ & \multicolumn{2}{c}{ Browning intensity (OD value) } \\
\cline { 5 - 6 } & 0.5 & $\left.80.12 \pm 0.15^{1) 22}\right)$ & $0.86 \pm 0.01^{\left.\mathrm{d}^{\star} 3\right)}$ & $0.08 \pm 0.01^{\mathrm{a}}$ \\
& 1 & $74.76 \pm 0.16^{\mathrm{d}}$ & $2.58 \pm 0.01^{\mathrm{e}^{*}}$ & $0.09 \pm 0.01^{\mathrm{a}}$ \\
40 & 2 & $67.72 \pm 0.96^{\mathrm{c}}$ & $0.33 \pm 0.01^{\mathrm{a}}$ & $0.08 \pm 0.01^{\mathrm{a}}$ \\
& 3 & $28.81 \pm 0.22^{\mathrm{b}}$ & $0.52 \pm 0.01^{\mathrm{b}}$ & $0.14 \pm 0.01^{\mathrm{b}}$ \\
& 4 & $3.80 \pm 0.16^{\mathrm{a}}$ & $0.55 \pm 0.01^{\mathrm{c}}$ & $0.99 \pm 0.01^{\mathrm{c}^{*}}$ \\
\hline & 0.5 & $74.65 \pm 0.16^{\mathrm{e}}$ & $0.23 \pm 0.01^{\mathrm{a}}$ & $0.09 \pm 0.01^{\mathrm{a}}$ \\
& 1 & $55.69 \pm 0.15^{\mathrm{d}}$ & $0.41 \pm 0.02^{\mathrm{b}}$ & $0.12 \pm 0.01^{\mathrm{b}^{*}}$ \\
& 2 & $9.84 \pm 0.30^{\mathrm{c}}$ & $0.82 \pm 0.01^{\mathrm{c}^{*}}$ & $0.15 \pm 0.01^{\mathrm{c}^{*}}$ \\
& 3 & $2.08 \pm 0.11^{\mathrm{b}}$ & $0.85 \pm 0.01^{\mathrm{d}^{*}}$ & $0.19 \pm 0.01^{\mathrm{d}^{*}}$ \\
& 4 & $1.54 \pm 0.03^{\mathrm{a}}$ & $0.88 \pm 0.01^{\mathrm{e}^{*}}$ & $0.18 \pm 0.01^{\mathrm{d}}$ \\
\hline
\end{tabular}

${ }^{1)}$ All values are mean $\pm \mathrm{SD}(\mathrm{n}=3)$.

${ }^{2 / a e}$ Means with different superscripts within the same aging temperature are significantly different by Duncan's multiple range test $(p<0.05)$.

${ }^{3{ }^{*}}$ Means with superscripts between the same aging time are significantly different by Student's t-test $(\mathrm{p}<0.05)$.

Maillard 반응 중간생성물을 측정하는 $280 \mathrm{~nm}$ 와 Maillard 반응 최종생성물을 측정하는 $420 \mathrm{~nm}$ 에서 각각 흡광도를 측정하여 숙성 온도를 달리한 새싹인삼의 갈변도를 확인한 결과 $40^{\circ} \mathrm{C}$ 에서 숙성한 새싹인삼의 $280 \mathrm{~nm}$ 에서 갈변도는 숙성 1 일에 흡광도 값 2.58 로 최고치를 보인이후 급격히 감소하여 숙성 4 일에는 0.55 였다. 반면 $60^{\circ} \mathrm{C}$ 에서 숙성한 새싹인삼의 갈변도는 숙성 2 일까지는 흡광도 값이 약 2 배 씩 증가하다가 이후부터는 증가 속도가 완만해졌으며 숙성 4 일에 0.88 로 가장 높았다. $420 \mathrm{~nm}$ 에서 흡광도는 $40^{\circ} \mathrm{C}$ 숙성 시 숙성 2 일까지는 유의적인 변화가 없었으며 숙성 3 일에 0.14 로 증가하였고, 숙성 4 일에는 0.99 로 급격히 증가하였 다. 반면 $60^{\circ} \mathrm{C}$ 에서 숙성한 새싹인삼의 흡광도는 유의적으 로 증가하다가 숙성 3일에 0.19로 최고치를 보인 이후에는 유의적인 변화가 없었다.

본 연구의 결과, 숙성 온도에 따라 갈변물질의 생성 정도 가 서로 상이하여, 상대적으로 저온에서 숙성할 경우는 갈 변물질의 중간 생성물이 숙성 초기에 급격히 증가하고, 최 종 생성물은 숙성 후기에 급증하였다. 반면 고온에서 숙성 할 경우에는 숙성 초기에 갈변 중간물질의 생성속도가 빨랐
으며 갈변반응의 최종 생성물의 증가는 상대적으로 완만하 였다. 이러한 차이는 $40^{\circ} \mathrm{C}$ 에서 숙성시킬 경우 polyphenol oxidase 등의 갈변 효소가 숙성 초기에 작용하여 숙성 후기 에는 갈변물질이 축적되기 때문이며, $60^{\circ} \mathrm{C}$ 에서는 숙성 초 기 효소적 갈변이 짧은 시간 동안 급격히 이루어진 후 비효 소적 갈변 반응이 서서히 유도되기 때문으로 추정된다.

$70-90^{\circ} \mathrm{C}$ 범위에서 온도를 달리하여 숙성한 흑양파 물 추출물은 숙성 온도가 더 높을수록 갈변도도 더 높았는데, 이는 유리당, 아미노산 등의 성분을 가용성 전분이 코팅하 는 효과, calcium chloride의 amino-carbonyl 반응 저해효과 및 $\beta$-cyclodextrin의 포접효과에 의한 것으로 추정되고 있다 (26). $90^{\circ} \mathrm{C}$ 정도의 고온에서 마늘을 숙성시킬 때 갈변반응은 가열 초기에 일어나는데, 이는 polyphenol oxidase가 50-7 $0^{\circ} \mathrm{C}$ 에서 활성을 잃기 때문이며, 숙성 24 시간 이후의 갈변반 응은 주로 비효소적 갈변이 주요인이라는 Lee 등(27)의 보 고도 있다.

\section{가용성 고형분, 조사포닌 및 총 페놀화합물의 함량}

숙성 온도를 달리한 새싹인삼 추출물의 가용성 고형분, 조사포닌, 총 페놀화합물의 함량을 분석한 결과는 Table 2 와 같다. 숙성 온도에 따른 가용성 고형분의 변화는 서로 상이한 경향을 보였는데, $40^{\circ} \mathrm{C}$ 숙성 새싹인삼은 숙성 3 일까 지는 가용성 고형분 함량이 증가하여 $3.77{ }^{\circ} \mathrm{Brix}$ 로 최고치 를 보인 후 숙성 4 일에는 $3.02{ }^{\circ} \mathrm{Brix}$ 로 감소하였다. $60^{\circ} \mathrm{C}$ 숙성 새싹인삼은 숙성 12 시간에 비해 숙성 24 시간에 가용 성 고형분이 약 2.2 배 증가하여 $2.07{ }^{\circ} \mathrm{Brix}$ 였고, 숙성 2 일에 $3.33{ }^{\circ} \mathrm{Brix}$ 로 가장 높았으며, 그 이후부터는 숙성 기간의 경과와 더불어 가용성 고형분은 오히려 감소하였다.

온도에 차이를 두어 증숙한 인삼 추출물의 가용성 고형 분은 $95^{\circ} \mathrm{C}$ 에서 3 시간 증숙 후 추출하였을 때 $10.7{ }^{\circ} \mathrm{Brix}$ 로 증숙하지 않고 동일조건에서 추출한 시료에 비해 약 3-4 ${ }^{\circ} \mathrm{Brix}$ 정도 더 높았으며, $121^{\circ} \mathrm{C}$ 에서 15 분간 증숙한 후 추출 하였을 때 $11.2^{\circ} \mathrm{Brix}$ 로 가장 높아 전처리 과정을 통해 가용 성 고형분이 증가하며, 온도가 높을수록 증가폭이 더 크다 는 보고(14)는 본 연구의 결과와 유사한 경향이었다.

본 연구에서 숙성 기간이 경과할수록 가용성 고형분의 함량이 증가하여 숙성 2-3일 정도에 최고치를 보인 후 감소 한 것은 볶음 보리 추출물에서 비가용성의 고분자 성분이 가용성 성분으로 분해되면서 수율이 증가하지만 볶음 시간 이 길어지면 불용성 화합물이 생성되어 수율이 오히려 감소 한다는 보고(28)로 미루어 볼 때 일정 숙성 시간이 지나면서 장시간 지속된 열처리에 의해 불용성 화합물이 생성되기 때문으로 추정된다.

사포닌은 인삼의 대표적인 성분의 하나로 비당체의 분자 구조에 따라 크게 protopanaxadiol(PPD)계, protopanaxatriol (PPT)계 및 olenane계 등 세 종류로 나뉜다(29). 또한 비당체 의 주요 부분에 에테르와 결합된 당의 종류와 수에 따라 
Table 2. Soluble solids, crude saponin contents and total phenolic compounds of aged Panax ginseng sprout with different temperature

\begin{tabular}{|c|c|c|c|c|}
\hline $\begin{array}{l}\text { Aging temperature } \\
\left({ }^{\circ} \mathrm{C}\right)\end{array}$ & $\begin{array}{l}\text { Aging time } \\
\text { (days) }\end{array}$ & $\begin{array}{l}\text { Soluble solids } \\
\left.\text { ( }{ }^{\circ} \text { Brix }\right)\end{array}$ & $\begin{array}{l}\text { Crude saponin } \\
(\%)\end{array}$ & $\begin{array}{l}\text { Total phenolic compounds } \\
\text { (mg GAE / } 100 \mathrm{~g} \text { ) }\end{array}$ \\
\hline \multirow{5}{*}{40} & 0.5 & $0.98 \pm 0.01^{\left.1 / 22)^{*} \times 3\right)}$ & $2.10 \pm 0.04^{\mathrm{a}}$ & $118.5 \pm 0.5^{\mathrm{a}}$ \\
\hline & 1 & $1.15 \pm 0.01^{\mathrm{b}}$ & $2.72 \pm 0.11^{\mathrm{c}}$ & $143.3 \pm 0.4^{b}$ \\
\hline & 2 & $1.90 \pm 0.01^{\mathrm{c}}$ & $2.31 \pm 0.04^{b}$ & $170.6 \pm 0.3^{c}$ \\
\hline & 3 & $3.77 \pm 0.01^{\left.\mathrm{e}^{* 2}\right)}$ & $6.86 \pm 0.18^{d}$ & $258.3 \pm 0.4^{d}$ \\
\hline & 4 & $3.02 \pm 0.01^{d^{*}}$ & $9.78 \pm 0.22^{2^{*}}$ & $341.3 \pm 0.6^{\mathrm{e}}$ \\
\hline \multirow{5}{*}{60} & 0.5 & $0.93 \pm 0.01^{\mathrm{a}}$ & $1.91 \pm 0.14^{\mathrm{a}}$ & $123.5 \pm 0.1^{a^{*}}$ \\
\hline & 1 & $2.07 \pm 0.01^{c^{*}}$ & $4.04 \pm 0.03^{\mathrm{b}^{*}}$ & $177.7 \pm 0.1^{b^{*}}$ \\
\hline & 2 & $3.33 \pm 0.01^{\mathrm{e}^{*}}$ & $6.07 \pm 0.05^{5^{c^{*}}}$ & $366.0 \pm 1.4^{c^{*}}$ \\
\hline & 3 & $2.09 \pm 0.01^{\mathrm{d}}$ & $8.57 \pm 0.19^{\mathrm{d}^{*}}$ & $431.5 \pm 2.4^{\mathrm{e}^{*}}$ \\
\hline & 4 & $1.56 \pm 0.01^{\mathrm{b}}$ & $8.39 \pm 0.11^{\mathrm{d}}$ & $396.2 \pm 0.9^{\mathrm{d}^{*}}$ \\
\hline
\end{tabular}

\footnotetext{
${ }^{1)}$ All values are mean $\pm \mathrm{SD}(\mathrm{n}=3)$.

2)a-e Means with different superscripts within the same aging temperature are significantly different by Duncan's multiple range test $(\mathrm{p}<0.05)$.

${ }^{3)^{*}}$ Means with superscripts between the same aging time are significantly different by Student's $\mathrm{t}$-test $(\mathrm{p}<0.05)$.
}

다양한 사포닌 종류가 분리된다고 알려져 있다(30).

새싹인삼의 사포닌 함량은 $40^{\circ} \mathrm{C}$ 숙성 새싹인삼의 경우 숙성 초기 $2.10 \%$ 이던 것이 숙성 2 일에는 $2.31 \%$ 로 유의적인 차이를 보였으나 증가폭이 크지 않았고 숙성 3일과 4일에 는 각각 $6.86 \%$ 와 $9.78 \%$ 로 급격히 증가하였다. $60^{\circ} \mathrm{C}$ 에서 숙성시킨 새싹인삼의 조사포닌 함량은 숙성 3일까지는 지 속적으로 증가하는 경향을 보여 숙성 12 시간에 $1.91 \%$ 이던 것이 숙성 3 일에는 $8.57 \%$ 로 약 4.5 배 증가하였으며, 숙성 4 일에는 유의적인 차이가 없었다.

Yoon(31)은 조건을 달리하여 증숙처리 하였을 때 인삼의 조사포닌 함량은 증숙온도가 높고, 시간이 길수록 더 많이 증가하였으며 증숙온도 보다는 시간이 조사포닌 함량 변화 에 영향을 미친다고 보고한 바 있다. 본 연구의 결과에서도 숙성온도가 높고, 숙성 기간이 길어질수록 조사포닌의 함 량은 증가하여 동일한 경향이었다.

$40^{\circ} \mathrm{C}$ 와 $60^{\circ} \mathrm{C}$ 로 숙성 온도를 달리하여 4 일간 숙성시킨 새싹인삼의 총 페놀화합물 함량(Table 2)은 $40^{\circ} \mathrm{C}$ 보다는 6 $0^{\circ} \mathrm{C}$ 에서 숙성한 새싹인삼에서 유의적으로 더 높았다. $40^{\circ} \mathrm{C}$ 숙성 새싹인삼의 총 페놀화합물 함량은 숙성 기간의 경과와 더불어 지속적으로 증가하는 경향이었는데, 숙성 12 시간에 $118.5 \mathrm{mg} \mathrm{GAE} / 100 \mathrm{~g}$ 이던 것이 숙성 4 일에는 $341.3 \mathrm{mg}$ $\mathrm{GAE} / 100 \mathrm{~g}$ 으로 약 2.9 배 더 증가하였다. $60^{\circ} \mathrm{C}$ 에서 숙성한 새싹인삼의 경우 숙성 3 일까지는 지속적으로 총 페놀화합 물의 함량이 증가하여 $431.5 \mathrm{mg} \mathrm{GAE} / 100 \mathrm{~g}$ 으로 최고치를 보인 이후 숙성 4일에는 $396.2 \mathrm{mg} \mathrm{GAE} / 100 \mathrm{~g}$ 으로 유의적으 로 감소하였다.

마늘의 경우 숙성 중 총 페놀화합물의 함량은 갈변도가 증가함에 따라 유의적으로 증가하였으며, $60^{\circ} \mathrm{C}$ 에서 숙성하 였을 때는 숙성 후반기에 그 함량이 급격히 증가하는 현상 을 보이는데 이는 열처리 공정에 의해 마늘 중 일부 화합물
이 페놀성 물질로 전환되었거나 열처리로 조직이 연화되어 페놀화합물들이 유리됨으로써 저분자의 페놀화합물의 농 도가 증가하거나 추출이 용이해 졌기 때문이라고 보고되어 있다(27). 본 연구의 결과에서도 숙성 기간 동안의 열에 의해 페놀화합물들의 유리가 용이해짐에 따라 숙성 기간의 경과와 더불어 그 함량이 증가한 것으로 생각된다.

\section{Chlorophyll의 함량 변화}

클로로필은 porphyrin핵에 마그네슘 이온이 결합된 형태 의 구조를 가지고 있으며, 마그네슘은 클로로필 색의 요인 이 되고 클로로필은 a, b, c, d 등으로 구성되어 있는데 육지 식물에 존재하는 porphyrin 계열 클로로필에는 C-3 탄소에 methyl group을 가지고 있는 클로로필 a와 formyl group이 결합되어 있는 클로로필 $\mathrm{b}$ 가 있다(32,33). 클로로필 $\mathrm{a}$ 는 청 록색, 클로로필 b는 황록색을 나타내며, 채소와 과일의 신 선함을 나타내는 지표가 되기도 한다(34,35).

숙성 기간별 새싹인삼의 클로로필 $\mathrm{a}, \mathrm{b}$ 및 총량을 정량한 결과는 Table 3 과 같다. 숙성 기간의 경과와 더불어 클로로 필 $\mathrm{a}$ 와 $\mathrm{b}$ 의 합인 총 클로로필의 함량은 증가하는 경향이었 다. 클로로필 $\mathrm{a}$ 의 경우 $40^{\circ} \mathrm{C}$ 에서 숙성하였을 때 숙성 3 일에 $259.82 \mathrm{mg} / 100 \mathrm{~g}$ 으로 숙성 2일에 비해 약 2.7 배 더 증가한 후 숙성 4 일에는 $270.71 \mathrm{mg} / 100 \mathrm{~g}$ 이었고, $60^{\circ} \mathrm{C}$ 에서 숙성한 시료의 경우 숙성 2 일에 $282.85 \mathrm{mg} / 100 \mathrm{~g}$ 으로 증가한 후 소량씩 감소하여 숙성 4 일에는 $270.89 \mathrm{mg} / 100 \mathrm{~g}$ 으로 $40^{\circ} \mathrm{C}$ 숙성 시료와 유의적인 차이가 없었다. 클로로필 $\mathrm{b}$ 는 숙성 12 시간에는 40 과 $60^{\circ} \mathrm{C}$ 숙성시료에서 각각 $25.46 \mathrm{mg} / 100$ $\mathrm{g}$ 과 $39.25 \mathrm{mg} / 100 \mathrm{~g}$ 이던 것이 숙성 기간의 경과와 더불어 그 함량이 증가하여 $40^{\circ} \mathrm{C}$ 숙성 시료에서는 숙성 4 일에 $488.58 \mathrm{mg} / 100 \mathrm{~g}$ 으로 클로로필 $\mathrm{a}$ 에 비해 1.8 배 정도 더 높았 으며, $60^{\circ} \mathrm{C}$ 숙성 시료의 경우 숙성 2 일부터 클로로필 $\mathrm{a}$ 에 
비해 그 함량이 더 높았고, 숙성 4 일에는 $467.03 \mathrm{mg} / 100$ $\mathrm{g}$ 으로 숙성 12 시간에 비해 약 11.9 배가 더 증가하였다.

토마토, 참외, 멜론, 사과, 수박 등의 과채류는 열처리 온도가 증가할수록 폴리페놀, 플라보노이드 함량과 항산화 활성이 높게 나타나며, $50^{\circ} \mathrm{C}$ 이상의 열처리에 의해 단백질 과 약한 결합상태로 있던 클로로필이 유리되어 함량이 증가 한다고 보고되어 있다(36,37). 본 연구의 결과에서도 열처 리 숙성을 통해 클로로필 함량이 증가하였으며, 숙성 온도 가 높을수록 증가속도가 더 빨라 동일한 경향이었다. $40^{\circ} \mathrm{C}$ 새싹인삼에서 더 높았다. 즉, $\mathrm{Rg} 3$ 의 경우 $40^{\circ} \mathrm{C}$ 숙성 새싹인삼에서는 숙성 12 시간에 $1.01 \mathrm{mg} / 100 \mathrm{~g}$ 이던 것이 숙성 4 일에는 약 7.6 배 증가하여 $7.64 \mathrm{mg} / 100 \mathrm{~g}$ 이었고, $60^{\circ} \mathrm{C}$ 숙성 새싹인삼에서는 $1.23 \mathrm{mg} / 100 \mathrm{~g}$ 이던 것이 약 3.6 배 더 증가하여 숙성 4 일에는 $4.47 \mathrm{mg} / 100 \mathrm{~g}$ 이었다.

인삼의 기능성분 및 생리활성 증진을 위한 열처리 방법 의 최적화의 연구 결과 수삼의 주요 진세노사이드인 $\mathrm{Re}$, $\mathrm{Rb} 1, \mathrm{Rg} 1$ 은 온도가 높고 증숙 횟수가 늘어날수록 그 함량이 증가한다는 보고 $(27,29)$ 가 있는가 하면 $\mathrm{Rg} 3$ 와 $\mathrm{Rh} 2$ 는 동일

Table 3. Chlorophyll contents of aged Panax ginseng sprout with different temperature

\begin{tabular}{|c|c|c|c|c|}
\hline $\begin{array}{l}\text { Aging temperature } \\
\left({ }^{\circ} \mathrm{C}\right)\end{array}$ & $\begin{array}{l}\text { Aging time } \\
\text { (days) }\end{array}$ & Chlorophyll a & Chlorophyll b & Total chlorophyll \\
\hline \multirow{5}{*}{40} & 0.5 & $54.89 \pm 0.13^{1 / 2)}$ & $25.46 \pm 0.18^{\mathrm{a}}$ & $80.34 \pm 0.28^{\mathrm{a}}$ \\
\hline & 1 & $114.34 \pm 0.14^{c}$ & $64.39 \pm 0.26^{b}$ & $178.73 \pm 0.18^{c}$ \\
\hline & 2 & $98.02 \pm 0.25^{b}$ & $66.80 \pm 0.03^{c}$ & $164.82 \pm 0.27^{\mathrm{b}}$ \\
\hline & 3 & $259.82 \pm 0.12^{\mathrm{d}}$ & $194.97 \pm 0.21^{\mathrm{d}}$ & $454.79 \pm 0.25^{\mathrm{d}}$ \\
\hline & 4 & $270.71 \pm 0.23^{\mathrm{e}}$ & $488.58 \pm 0.51^{\left.\mathrm{e}^{*} 3\right)}$ & $759.29 \pm 0.62^{\mathrm{e}^{*}}$ \\
\hline \multirow{5}{*}{60} & 0.5 & $56.14 \pm 0.15^{\mathrm{a}^{*}}$ & $39.35 \pm 0.17^{\mathrm{a}^{*}}$ & $95.49 \pm 0.10^{\mathrm{a}^{*}}$ \\
\hline & 1 & $154.12 \pm 0.07^{\mathrm{b}^{\mathrm{t}}}$ & $98.26 \pm 0.12^{\mathrm{b}^{*}}$ & $252.38 \pm 0.14^{b^{*}}$ \\
\hline & 2 & $282.85 \pm 0.17^{7^{*}}$ & $311.61 \pm 0.61^{1^{*}}$ & $594.46 \pm 0.47^{7^{\star}}$ \\
\hline & 3 & $275.35 \pm 0.10^{\mathrm{d}^{\star}}$ & $418.52 \pm 0.26^{\mathrm{d}^{\star}}$ & $693.87 \pm 0.17^{\mathrm{d}^{\star}}$ \\
\hline & 4 & $270.89 \pm 0.12^{\mathrm{c}}$ & $467.03 \pm 0.21^{\mathrm{e}}$ & $737.91 \pm 0.25^{\mathrm{e}}$ \\
\hline
\end{tabular}

${ }^{1)}$ All values are mean $\pm \mathrm{SD}(\mathrm{n}=3)$.

2)a- Means with different superscripts within the same aging temperature are significantly different by Duncan's multiple range test $(\mathrm{p}<0.05)$.

${ }^{3)^{*}}$ Means with superscripts between the same aging time are significantly different by Student's $t$-test $(p<0.05)$.

\section{진세노사이드의 함량 변화}

Table 4에서와 같이 숙성을 거치지 않은 새싹인삼의 진세 노사이드 총량은 $34.11 \mathrm{mg} / 100 \mathrm{~g}$ 이었는데 이 중 $\mathrm{Re}$ 의 함량 이 $18.62 \mathrm{mg} / 100 \mathrm{~g}$ 으로 가장 높아 전체 진세노사이드의 $54.6 \%$ 를 차지하였다. 다음으로 $\operatorname{Rg} 1$ 의 함량이 $6.38 \mathrm{mg} / 100$ $\mathrm{g}$ 으로 높았고, 여타 진세노사이드의 함량은 $2 \mathrm{mg} / 100 \mathrm{~g}$ 미만이었다.

숙성을 거치면서 새싹인삼의 진세노사이드 함량은 증가 하는 경향으로 숙성 12시간에 비해 숙성 4일에 약 2.5-6.0배 정도 그 함량이 증가하였다. 숙성 12 시간을 기준으로 볼 때 진세노사이드의 총량은 $40^{\circ} \mathrm{C}$ 숙성 새싹인삼에서는 $38.28 \mathrm{mg} / 100 \mathrm{~g}$ 이었고 $60^{\circ} \mathrm{C}$ 숙성 시에는 $44.50 \mathrm{mg} / 100 \mathrm{~g}$ 이 었는데 $40^{\circ} \mathrm{C}$ 숙성 새싹인삼의 경우 숙성 4 일에 201.56 $\mathrm{mg} / 100 \mathrm{~g}$ 으로 함량이 유의적으로 높았다. $60^{\circ} \mathrm{C}$ 숙성 새싹인 삼에서도 진세노사이드 총량은 증가하는 경향을 보여 숙성 3 일에 $199.50 \mathrm{mg} / 100 \mathrm{~g}$ 으로 가장 높은 함량이었으며, 이러 한 경향은 본 연구의 조사포닌의 함량변화와 유사하였다. 또한 대부분의 진세노사이드가 숙성 12 시간에는 $60^{\circ} \mathrm{C}$ 숙성 새싹인삼에서 더 높았으나 숙성이 진행되면서 그 증가폭은
한 조건에서 반복해서 증자할 때 3회 증자시까지는 그 함량 이 증가하지만 그 이상 증자 시는 그 함량이 일부 감소하거 나 더 이상 증가하지 않는다는 보고도 있다(38).

열처리 시 진세노사이드의 함량은 조건에 따라 증가하거 나 감소하게 되는데, 진세노사이드의 분자량에 따라서도 변화가 상이하며 증가하는 요인으로는 고온에서 장시간 처리시 고분자의 진세노사이드 잔기에 붙어 있는 당의 가수 분해가 용이해 지면서 저분자 진세노사이드로의 전환이 용이해지고 세포벽의 구조 변형 또는 파괴로 인해 진세노사 이드의 용출량이 상이하기 때문으로 추정되고 있다(38). 본 연구의 결과, 숙성 온도, 시간 및 진세노사이드에 따라 함량의 변화 경향이 서로 상이한 것도 이처럼 열에 의해 가수분해력이 상이하고, 열처리에 따른 세포벽의 손상 정 도가 상이하여 진세노사이드의 분해정도나 용출 정도에 영향을 미쳤기 때문으로 생각된다.

\section{항산화활성}

방향족 화합물 및 방향족 아민류에 의해 환원되어 자색 이 탈색되는 정도를 통해 항산화활성을 측정하는 방법(26) 
Table 4. Ginsenosides contents of aged Panax ginseng sprout with different temperature

$(\mathrm{mg} / 100 \mathrm{~g})$

\begin{tabular}{|c|c|c|c|c|c|c|c|c|c|c|c|c|}
\hline $\begin{array}{l}\text { Aging } \\
\text { temp. } \\
\left({ }^{\circ} \mathrm{C}\right)\end{array}$ & $\begin{array}{c}\text { Aging } \\
\text { time } \\
\text { (days) }\end{array}$ & $\operatorname{Re}$ & $\operatorname{Rg} 1$ & $\mathrm{Rf}$ & $\mathrm{Rb} 1$ & Rg2 & Rhl & $\mathrm{Rb} 2$ & $\mathrm{Rd}$ & $\mathrm{Rg} 3$ & $\mathrm{Rh} 2$ & Total \\
\hline \multicolumn{2}{|c|}{$C^{1)}$} & $18.62 \pm 2.25^{2)}$ & $6.38 \pm 0.58$ & $1.08 \pm 0.08$ & $1.92 \pm 0.42$ & $1.76 \pm 0.21$ & $0.79 \pm 0.44$ & $0.64 \pm 0.22$ & $0.58 \pm 0.21$ & $0.93 \pm 0.08$ & $1.41 \pm 0.25$ & $34.11 \pm 4.75$ \\
\hline \multirow{5}{*}{40} & 0.5 & $19.67 \pm 0.95^{\mathrm{a} 3)}$ & $7.88 \pm 0.00^{\mathrm{a}}$ & $1.23 \pm 0.08^{\mathrm{a}}$ & $3.36 \pm 0.35^{a^{*}}$ & $1.73 \pm 0.11^{\mathrm{a}}$ & $1.05 \pm 0.93^{\mathrm{a}}$ & $0.99 \pm 0.23^{\mathrm{a}}$ & $0.82 \pm 0.12^{\mathrm{a}}$ & $1.01 \pm 0.65^{\mathrm{a}}$ & $0.54 \pm 0.07^{\mathrm{a}}$ & $38.28 \pm 3.50^{\mathrm{a}}$ \\
\hline & 1 & $26.34 \pm 0.26^{\left.6^{\star 4}\right)}$ & $11.74 \pm 1.26^{\mathrm{a}}$ & $1.69 \pm 0.05^{\mathrm{a}}$ & $5.09 \pm 0.87^{b^{*}}$ & $2.97 \pm 0.20^{b}$ & $2.27 \pm 0.14^{\mathrm{ab}^{\mathrm{a}}}$ & $1.58 \pm 0.17^{\mathrm{a}^{*}}$ & $1.48 \pm 0.19^{\mathrm{ab}}$ & $1.08 \pm 0.74^{\mathrm{a}}$ & $1.54 \pm 0.10^{b}$ & $55.76 \pm 3.98^{b^{*}}$ \\
\hline & 2 & $38.02 \pm 2.42^{c^{*}}$ & $19.28 \pm 2.59^{b}$ & $2.53 \pm 0.40^{b *}$ & $8.20 \pm 0.86^{c^{*}}$ & $3.73 \pm 0.57^{b^{*}}$ & $3.79 \pm 0.36^{6^{*}}$ & $2.85 \pm 0.32^{b^{*}}$ & $2.62 \pm 0.51^{b^{*}}$ & $1.42 \pm 0.94^{\mathrm{a}}$ & $1.21 \pm 0.31^{\mathrm{bc}^{*}}$ & $83.65 \pm 9.29^{c^{*}}$ \\
\hline & 3 & $73.68 \pm 0.59^{d}$ & $22.49 \pm 7.84^{b}$ & $5.20 \pm 0.47^{c}$ & $12.87 \pm 0.46^{\mathrm{d}^{*}}$ & $8.25 \pm 0.71^{c^{*}}$ & $8.80 \pm 1.46^{c}$ & $6.05 \pm 0.08^{c^{*}}$ & $5.10 \pm 0.50^{c^{*}}$ & $4.94 \pm 0.36^{b^{*}}$ & $1.72 \pm 0.17^{c^{*}}$ & $149.11 \pm 12.64^{\mathrm{d}^{*}}$ \\
\hline & 4 & $101.87 \pm 1.34^{e}$ & $24.5 \pm 0.99^{b^{*}}$ & $6.61 \pm 0.30^{d}$ & $19.72 \pm 1.10^{\circ}$ & $10.51 \pm 0.97^{\mathrm{d}}$ & $10.88 \pm 1.45^{\mathrm{d}}$ & $10.05 \pm 1.09^{d}$ & $7.92 \pm 1.30^{\mathrm{d}}$ & $7.64 \pm 0.75^{\mathrm{c}}$ & $1.86 \pm 0.20^{c}$ & $201.56 \pm 9.48^{\mathrm{e}}$ \\
\hline \multirow{5}{*}{60} & 0.5 & $20.23 \pm 2.71^{\mathrm{a}}$ & $8.87 \pm 0.87^{a}$ & $1.76 \pm 0.38^{\mathrm{a}}$ & $4.24 \pm 0.29^{\mathrm{a}^{*}}$ & $2.18 \pm 0.40^{\mathrm{a}}$ & $2.22 \pm 0.82^{\mathrm{a}}$ & $1.83 \pm 0.54^{\mathrm{a}}$ & $1.40 \pm 0.47^{\mathrm{a}}$ & $1.23 \pm 0.53^{\mathrm{a}}$ & $0.55 \pm 0.16^{\mathrm{a}}$ & $44.50 \pm 7.18^{\mathrm{a}}$ \\
\hline & 1 & $41.93 \pm 0.83^{b^{b^{*}}}$ & $17.18 \pm 2.86^{b}$ & $3.11 \pm 0.65^{\mathrm{b}}$ & $9.68 \pm 0.80^{b^{*}}$ & $4.83 \pm 0.97^{b}$ & $5.20 \pm 0.45^{b^{*}}$ & $3.18 \pm 0.37^{b^{*}}$ & $2.95 \pm 0.86^{\mathrm{a}}$ & $2.15 \pm 0.61^{\mathrm{a}}$ & $0.99 \pm 0.28^{b}$ & $91.21 \pm 8.68^{b^{*}}$ \\
\hline & 2 & $80.74 \pm 1.4 \mathrm{c}^{\mathrm{c}^{*}}$ & $21.08 \pm 1.38^{\mathrm{bc}}$ & $5.79 \pm 0.47^{c^{\star}}$ & $23.34 \pm 0.73^{c^{*}}$ & $10.09 \pm 0.78^{c^{*}}$ & $10.18 \pm 0.05^{c^{*}}$ & $8.67 \pm 0.01^{c^{*}}$ & $9.09 \pm 0.16^{b^{*}}$ & $1.15 \pm 0.68^{\mathrm{a}}$ & $2.23 \pm 0.15^{\mathrm{d}^{\mathrm{d}}}$ & $172.37 \pm 5.82^{c^{*}}$ \\
\hline & 3 & $96.56 \pm 9.23^{\mathrm{d}}$ & $26.9 \pm 7.04^{c}$ & $6.56 \pm 0.90^{c}$ & $22.56 \pm 0.93^{c^{*}}$ & $11.06 \pm 0.79^{c^{*}}$ & $11.81 \pm 0.32^{d}$ & $10.16 \pm 0.47^{\mathrm{d}^{*}}$ & $10.58 \pm 0.80^{b^{*}}$ & $1.01 \pm 0.54^{a^{*}}$ & $2.30 \pm 0.26^{\mathrm{d}^{\mathrm{d}}}$ & $199.50 \pm 21.29^{\mathrm{cd} d^{\star}}$ \\
\hline & 4 & $87.28 \pm 4.35^{\mathrm{c}}$ & $22.00 \pm 1.02^{\mathrm{bc}^{*}}$ & $6.05 \pm 0.41^{\mathrm{c}}$ & $25.39 \pm 3.02^{c}$ & $10.30 \pm 0.95^{c}$ & $13.60 \pm 0.05^{\mathrm{e}}$ & $11.49 \pm 0.90^{\mathrm{e}}$ & $9.68 \pm 1.69^{b}$ & $4.47 \pm 1.53^{\mathrm{b}}$ & $1.56 \pm 0.22^{c}$ & $191.82 \pm 14.13^{\mathrm{d}}$ \\
\hline
\end{tabular}

${ }^{1)} \mathrm{C}$, fresh Panax ginseng sprout.

${ }^{2)}$ All values are mean $\pm \mathrm{SD}(\mathrm{n}=3)$.

${ }^{3) a-c}$ Means with different superscripts within the same aging temperature are significantly different by Duncan's multiple range test $(\mathrm{p}<0.05)$.

${ }^{4)^{*}}$ Means with superscripts between the same aging time are significantly different by Student's $t$-test $(p<0.05)$.

Table 5. Antioxidation activity of aged Panax ginseng sprout with different temperature

$(\%)$

\begin{tabular}{|c|c|c|c|}
\hline \multirow{2}{*}{$\begin{array}{l}\text { Aging temperature } \\
\left({ }^{\circ} \mathrm{C}\right)\end{array}$} & \multirow{2}{*}{$\begin{array}{l}\text { Aging time } \\
\text { (days) }\end{array}$} & \multicolumn{2}{|c|}{ Radical scavenging activity } \\
\hline & & DPPH & ABTS \\
\hline \multirow{5}{*}{40} & 0.5 & $13.65 \pm 0.54^{\left.1)_{2} 2\right)}$ & $25.79 \pm 1.33 b^{* 3)}$ \\
\hline & 1 & $19.86 \pm 1.17^{b}$ & $24.01 \pm 0.46^{\mathrm{a}}$ \\
\hline & 2 & $20.90 \pm 1.88^{\mathrm{bc}}$ & $71.11 \pm 1.09^{d}$ \\
\hline & 3 & $24.71 \pm 1.05^{\mathrm{c}}$ & $88.58 \pm 0.43^{\mathrm{e}^{*}}$ \\
\hline & 4 & $22.59 \pm 2.18^{d}$ & $60.96 \pm 0.63^{\mathrm{c}^{*}}$ \\
\hline \multirow{5}{*}{60} & 0.5 & $18.82 \pm 0.65^{\mathrm{a}}$ & $20.13 \pm 0.44^{\mathrm{a}^{*}}$ \\
\hline & 1 & $21.29 \pm 0.98^{b}$ & $47.04 \pm 0.60^{b^{*}}$ \\
\hline & 2 & $26.36 \pm 2.34^{d}$ & $89.98 \pm 0.98^{\mathrm{e}^{*}}$ \\
\hline & 3 & $27.18 \pm 1.23^{\mathrm{d}^{*}}$ & $81.60 \pm 0.35^{\mathrm{d}}$ \\
\hline & 4 & $23.80 \pm 0.54^{c}$ & $54.40 \pm 0.56^{\mathrm{c}}$ \\
\hline \multirow{5}{*}{$\begin{array}{c}\text { Ascorbic acid } \\
\text { concentration } \\
(\mu \mathrm{g} / \mathrm{mL})\end{array}$} & 1.56 & $12.37 \pm 0.78$ & $22.25 \pm 1.45$ \\
\hline & 3.13 & $22.06 \pm 0.76$ & $39.50 \pm 1.13$ \\
\hline & 6.25 & $41.90 \pm 0.96$ & $75.03 \pm 1.76$ \\
\hline & 12.5 & $75.82 \pm 1.64$ & $100<$ \\
\hline & 25 & $95.97 \pm 0.34$ & $100<$ \\
\hline
\end{tabular}

Tested sample concentration was $10 \mathrm{mg} / \mathrm{mL}$.

${ }^{1)}$ All values are mean $\pm \mathrm{SD}(\mathrm{n}=3)$.

2)ar- Means with different superscripts within the same aging temperature are significantly different by Duncan's multiple range test $(\mathrm{p}<0.05)$.

${ }^{3)^{*}}$ Means with superscripts between the same aging time are significantly different by Student's t-test $(\mathrm{p}<0.05)$.
인 DPPH 라디칼 소거활성과 $\mathrm{ABTS}$ 라디칼 소거활성을 측 정한 결과는 Table 5 와 같다. DPPH 라디칼 소거활성은 숙성 기간의 경과와 더불어 점차 증가하는 경향을 보이면서 숙성 3 일에 $40^{\circ} \mathrm{C}$ 와 $60^{\circ} \mathrm{C}$ 숙성 시료에서 각각 $24.71 \%$ 와 $27.18 \%$ 로 가장 활성이 높았으며, 숙성 4 일에는 활성이 오히려 감소하 였다. Kang 등(39)은 DPPH 라디칼 소거활성은 페놀성 화합 물에 대한 항산화 작용의 지표이며 환원력이 클수록 활성이 높다고 하였다.

$\mathrm{ABTS}$ 라디칼 소거활성도 유사한 경향으로 $40^{\circ} \mathrm{C}$ 숙성 새싹인삼은 숙성 3 일에 $88.58 \%$ 로 활성이 가장 높았고, $60^{\circ} \mathrm{C}$ 숙성 새싹인삼은 숙성 2 일에 $89.98 \%$ 로 가장 활성이 높았는 데, 그 이후에는 활성이 유의적으로 감소하였다.

페놀화합물은 항산화활성을 나타내는 대표적인 화합물 로 열처리에 따른 페놀화합물의 증가로 항산화활성도 증가 하는 것으로 보고되어 있는데(40), 본 연구의 결과에서는 페놀화합물의 함량과 항산화활성이 일치하는 경향을 보이 지 않았다. 이는 곡물이나 과일은 총 페놀함량과 항산화성 사이의 상관성은 크지만 예외로 약용식물과 안토시안이 다량 함유되어 있는 과일에서는 상관성이 적다는 보고(41) 와 인삼 중에 함유된 페놀화합물이 DPPH 라디칼 중심에 접근하기 어려운 구조적 특성을 가지고 있기 때문이라는 보고(42) 및 인삼은 열처리 의해 페놀화합물, 진세노사이드 의 함량이 변화된다는 보고(40)로 미루어 볼 때 열처리 조건 에 따라 페놀화합물의 종류나 함량이 서로 상이하고, 페놀 화합물 이외의 미량 성분들이 함께 영향을 미치기 때문으로 추정된다. 


\section{콜레스테롤 흡착활성 및 $\mathrm{ACE}$ 저해능}

숙성 온도를 달리한 새싹인삼의 콜레스테롤 흡착활성과 $\mathrm{ACE}$ 저해활성을 측정한 결과는 Table 6과 같다. $40^{\circ} \mathrm{C}$ 에서 숙성한 새싹인삼의 콜레스테롤 흡착활성은 숙성 초기에는 $14.64 \%$ 이던 것이 숙성 2 일에 $22.70 \%$ 로 증가한 후 숙성 3 일까지는 유의적인 차이가 없었으나 숙성 4 일에는 $17.36 \%$ 로 활성이 낮아졌다. 반면 $60^{\circ} \mathrm{C}$ 에서 숙성한 새싹인삼의 경 우 숙성 초기 활성은 $11.39 \%$ 였으나 숙성 기간의 경과와 더불어 지속적으로 콜레스테롤 흡착활성이 증가하여 숙성 4 일의 활성은 $27.71 \%$ 였다.

Shin 등(43)의 연구에서는 고지혈증 및 심혈관계 질환의 활성이 우수한 소재를 검색한 결과 선별된 국내산 단삼을 $100 \%$ 주정(상온추출)과 물 $\left(70^{\circ} \mathrm{C}, 3\right.$ 시간) 추출하여 콜레스 테롤 흡착활성을 평가한 결과 이들의 활성은 각각 $20.14 \%$ 와 $26.62 \%$ 였고, 추출물간의 차이는 크지 않았다고 보고되 어 있다. 본 연구의 결과에서 $40^{\circ} \mathrm{C}$ 숙성 시료는 2-3일 숙성 하였을 때, $60^{\circ} \mathrm{C}$ 숙성 시료는 3-4일 숙성 하였을 때 단삼의 주정 추출물보다 높은 콜레스테롤 흡착활성을 나타내었다. 콜레스테롤 흡착활성에는 식이섬유와 더불어 생리활성 물질인 quercetine과 플라보노이드와 페놀화합물 등도 흡착 능을 증진시키는데 기여한다고 보고되어 있다(44). 본 연구 의 결과에서 숙성된 새싹인삼 추출물의 콜레스테롤 흡착활 성도 혈중 콜레스테롤 저하와 배설 촉진 효과가 있는 $\mathrm{Rb} 2$ 를 포함한 진세노사이드(45)와 플라보노이드 및 페놀화합물 등이 복합적으로 영향을 미쳤을 것으로 추정된다.

$\mathrm{ACE}$ 는 불활성형의 angiotensin-I(decapeptide)의 $\mathrm{C}$ 말단 에 존재하는 histidine-leucine을 절단하여 혈관별로 수축작

Table 6. Cholesterol absorption ability and ACE inhibition activity of aged Panax ginseng sprout with different temperature

$(\%)$

\begin{tabular}{|c|c|c|c|}
\hline $\begin{array}{l}\text { Aging temperature } \\
\left({ }^{\circ} \mathrm{C}\right)\end{array}$ & $\begin{array}{l}\text { Aging time } \\
\text { (days) }\end{array}$ & $\begin{array}{l}\text { Cholesterol absorption } \\
\text { ability }\end{array}$ & $\begin{array}{l}\text { ACE inhibition } \\
\text { activity }\end{array}$ \\
\hline \multirow{5}{*}{40} & 0.5 & $14.64 \pm 0.26^{(1,22) * 33)}$ & $58.03 \pm 1.85^{\mathrm{a}^{*}}$ \\
\hline & 1 & $19.95 \pm 0.24^{c^{*}}$ & $60.09 \pm 0.11^{\mathrm{b}}$ \\
\hline & 2 & $22.70 \pm 0.75 \mathrm{~d}^{*}$ & $60.47 \pm 0.40^{b}$ \\
\hline & 3 & $23.37 \pm 3.03^{d}$ & $82.56 \pm 0.23^{c^{\star}}$ \\
\hline & 4 & $17.36 \pm 0.27^{b}$ & $59.86 \pm 0.70^{b^{*}}$ \\
\hline \multirow{5}{*}{60} & 0.5 & $11.39 \pm 0.86^{\mathrm{a}}$ & $55.09 \pm 1.28^{\mathrm{a}}$ \\
\hline & 1 & $15.82 \pm 0.86^{b}$ & $72.80 \pm 0.64^{\mathrm{c}^{*}}$ \\
\hline & 2 & $17.11 \pm 2.34^{b}$ & $83.67 \pm 0.11^{\mathrm{d}^{\star}}$ \\
\hline & 3 & $21.01 \pm 0.84^{c}$ & $58.18 \pm 0.65^{b}$ \\
\hline & 4 & $27.71 \pm 1.48^{\mathrm{d}^{\star}}$ & $57.57 \pm 0.65^{\mathrm{b}}$ \\
\hline
\end{tabular}

Tested sample concentration was $100 \mathrm{mg} / \mathrm{mL}$.

${ }^{1)}$ All values are mean \pm SD $(n=3)$.

${ }^{2) a d}$ Means with different superscripts within the same aging temperature are significantly different by Duncan's multiple range test $(\mathrm{p}<0.05)$.

${ }^{3)^{*}}$ Means with superscripts between the same aging time are significantly different by Student's t-test $(\mathrm{p}<0.05)$.
용을 하는 angiotensin- П(octapeptide)를 생성하고 혈압을 감소시키는 bradykinin을 불활성화 시키는 효소이며 $\mathrm{ACE}$ 저해제는 $\mathrm{ACE}$ 작용을 저해하고 혈관수축을 방어하여 혈압 을 강하하는 효과를 가지고 있어 고혈압으로 인한 심장병의 치료제로 사용되고 있다(46).

$\mathrm{ACE}$ 저해활성은 $40^{\circ} \mathrm{C}$ 숙성 새싹인삼의 경우 숙성 2 일까 지는 활성이 $58.03-60.47 \%$ 의 범위였는데 숙성 3 일에 큰 폭 으로 활성이 증가하여 $82.56 \%$ 였고, 숙성 4 일에는 $59.86 \%$ 로 활성이 감소하였다. $60^{\circ} \mathrm{C}$ 숙성 새싹인삼의 경우 숙성 1 일에 활성이 $72.80 \%$ 로 숙성 12 시간에 비해 활성이 약 1.3 배 증가 한 후 숙성 2일에 $83.67 \%$ 로 가장 활성이 높았고, 숙성 3 일에 $58.18 \%$ 로 감소한 이후에는 유의적인 변화가 없었다.

이와 같은 $\mathrm{ACE}$ 저해활성의 변화는 진세노사이드의 함량 과 밀접한 관련이 있는 것으로 추정되는데, 본 연구결과에 서 $\mathrm{ACE}$ 저해활성이 $40^{\circ} \mathrm{C}$ 숙성 새싹인삼에서 3 일째에 큰 폭으로 증가한 것과 $60^{\circ} \mathrm{C}$ 숙성 새싹인삼에서 3,4 일의 결과 에 유의적 차이가 없는 것은 진세노사이드 총 함량과 동일 한 경향이었다.

Hwang 등(47)은 수경재배 한 인삼의 경우 열처리 온도 $\left(90,110,130\right.$ 및 $\left.150^{\circ} \mathrm{C}\right)$ 가 증가함에 따라 $\mathrm{ACE}$ 저해활성이 인삼 뿌리는 $10 \%$ 에서 $75 \%$ 로, 잎줄기는 $35 \%$ 에서 $80 \%$ 정도 로 증가한다고 보고한 바 있다. 본 연구의 결과에서도 $40^{\circ} \mathrm{C}$ 에서 숙성한 새싹인삼에 비해 $60^{\circ} \mathrm{C}$ 에서 숙성한 새싹인삼의 $\mathrm{ACE}$ 저해활성이 더 높아 동일한 경향이었다.

\section{요 약}

새싹인삼의 이화학적 특성과 생리 활성을 향상시킬 수 있는 가공 방법 모색을 위해 전처리를 거친 새싹인삼을 40 과 $60^{\circ} \mathrm{C}$ 에서 $0.5,1,2,3,4$ 일간 숙성시킨 후 유효성분 및 생리활성 변화를 비교분석하였다. 갈변도는 숙성 온도 가 높고, 숙성 기간이 경과함에 따라 증가하는 경향이었다. 조사포닌 함량은 숙성 초기에는 $60^{\circ} \mathrm{C}$ 숙성 시 더 높았으나 숙성 기간이 경과함에 따라 $40^{\circ} \mathrm{C}$ 숙성 시료에서 함량이 급격히 증가하여 $60^{\circ} \mathrm{C}$ 숙성 시료보다 유의적으로 더 높았 다. 총 페놀화합물의 함량은 숙성 기간이 지나면서 점차적 으로 증가하였는데 $40^{\circ} \mathrm{C}$ 에서 숙성하였을 때는 숙성 4 일에 $341.3 \mathrm{GAE} \mathrm{mg} / 100 \mathrm{~g}$ 으로 가장 높은 함량이었고 $60^{\circ} \mathrm{C}$ 에서 숙성하였을 때는 숙성 3 일에 $431.5 \mathrm{GAE} \mathrm{mg} / 100 \mathrm{~g}$ 로 가장 높은 함량이었다. 진세노사이드 중 $\mathrm{Re}, \mathrm{Rb} 1, \mathrm{Rg} 1$ 의 함량이 높았으며 숙성 초기에는 총 진세노사이드 함량이 $60^{\circ} \mathrm{C}$ 숙성 새싹인삼에서 더 높았으나 숙성 4일에는 숙성 온도에 따른 유의적인 함량 차이가 없었다. ABTS 라디칼 소거활성은 $40^{\circ} \mathrm{C}$ 숙성 새싹인삼은 숙성 3 일에 $88.58 \%$ 로 활성이 가장 높았고, $60^{\circ} \mathrm{C}$ 숙성 새싹인삼은 숙성 2 일에 $89.98 \%$ 로 가장 활성이 높았다. $40^{\circ} \mathrm{C}$ 에서 3 일 동안 숙성한 새싹인삼의 콜레 
스테롤 흡착활성은 $23.37 \%, \mathrm{ACE}$ 저해능은 $82.56 \%$ 로 가장 활성이 높았으나 $60^{\circ} \mathrm{C}$ 숙성 시료의 콜레스테롤 흡착능은 숙성 4일 시료가 $27.71 \%$ 로 가장 높았고, $\mathrm{ACE}$ 저해능은 숙성 2 일 시료가 $83.67 \%$ 로 가장 활성이 높았다. 이상의 결과를 종합하여 볼 때 숙성공정을 통해 새싹인삼의 진세노 사이드의 함량 증대나 생리활성의 증대가 가능하며, 이를 위해서는 $40^{\circ} \mathrm{C}$ 에서는 3 일, $60^{\circ} \mathrm{C}$ 에서는 2 일 정도 숙성하는 것이 적합한 것으로 판단된다.

\section{감사의 글}

본 논문은 중소벤처기업부의 지역주력산업육성사업 창 의융합 R\&D(R0006093) 과제 수행에 따른 연구 성과의 일 부이며 이에 감사드립니다.

\section{References}

1. Ko SR, Choi KJ, Kim YH (1996) Comparative study on the essential oil components of Panax species. Korean J Ginseng Res, 20, 42-48

2. Park CK, Kwak YS, Hwang MS, Kim SC, Do JH (2007) Trends and prospect of ginseng products in market health functional food. Food Science and Industry, 40, 30-45

3. Nam KY (2002) Clinical applications and efficacy of Korean ginseng. J Ginseng Res, 26, 111-131

4. Attele AS, Wu JA, Yuan CS (1999) Ginseng pharmacology: multiple constituents and multiple actions. Biochem Pharmacol, 58, 1685-1693

5. Jeon JM, Choi SK, Kim YJ, Jang SJ, Cheon JW, Lee HS (2011) Antioxidant and antiaging effect of ginseng berry extract fermented by lactic acid bacteria. J Soc Cosmet Scientists Korea, 37, 75-81

6. Kim SH (2008) Physiological activity biotransformation of ginsenosides isolated from ginseng leaves. MS Thesis, Kyonggi University, Korea, p 1-5

7. Achike FI, Kwan CY (2003) Nitric oxide, human diseases and the herbal products that affect the nitric oxide signalling pathway. Clin Exp Pharmacol Physiol, 30, 605-615

8. Kim YC, Hong HD, Rho JH, Cho CW, Rhee YK, Yim JH (2007) Changes of phenolic acid contents and radical scavenging activities of ginseng according to steaming times. J Ginseng Res, 31, 230-236

9. Kong YH, Rho JH, Cho CW, Kim MH, Lee YC, Kim SS, Lee PJ, Choi SY (2009) Variation of phenolic ingredient and ginsenoside content in red ginseng extract by acid treatment. J Ginseng Res, 33, 194-198

10. Choi CS, Kim KI, Hong HD, Choi SY, Lee YC, Kim KT, Rho JH, Kim SS, Kim YC (2006) Phenolic acid composition and antioxidative activity of white ginseng (Panax ginseng C. A. Meyer). J Ginseng Res, 30, 22-30

11. Yahara S, Tanaka O, Komori T (1976) Saponins of the leaves of Panax ginseng C. A. Meyer. Chem Pharm Bull, 24, 2204-2208

12. Lee KS, Seong BJ, Kim GH, Kim SI, Han SH, Kim HH, Baik ND (2010) Ginsenoside, phenolic acid composition and physiological significances of fermented ginseng leaf. J Korean Soc Food Sci Nutr, 39, 1194-1200

13. Seog HM, Jung CH, Kim YS, Park HS (2005) Phenolic acids and antioxidant activities of wild ginseng (Panax ginseng C. A. Meyer) leaves. Food Sci Biotechnol, 14, 371-374

14. Im GY, Jang SY, Jeong YJ (2010) Quality characteristics of Panax ginseng C. A. Meyer with steaming heat and wet grinding conditions. J Korean Soc Food Sci Nutr, 39, 1005-1010

15. Jeong HC, Hong HD, Kim YC, Rho J, Kim KT, Cho CW (2012) The research trend of ginseng processing technology and the status of ginseng industry. Food Science and Industry, 45, 59-67

16. Park MY (2017) A study on the optimization of wild-simulated ginseng in the forest. MS Thesis, Silla University, Korea, p 1-11

17. Jung HB (2018) Processing and quality characteristics of the high value-added seafood products using Panax ginseng sprout. Ph D Thesis, Gyeongsang National University, Korea, p 8

18. Kwak JG, Seong H, Han NS (2017) Development of manufacturing technology of Bacillus subtilis spores for long-term storage. 2017 KFN International Symposium and Annual Meeting, Korea, 10, 289

19. Kim KP, Kim KH, Yook HS (2016) Quality characteristics of castella with Panax ginseng sprout powder. J Korean Soc Food Sci Nutr, 45, 711-716

20. Jung HB, Seoung TJ, Kim JG (2017) Quality characteristics of sprout ginseng paste added dry oyster and dry shrimp. Culinary Sci Hos Res, 23, 206-215

21. Gutfinger T (1981) Polyphenols in olive oils. J Am Oil Chem Soc, 58, 966-968

22. Blois MS (1958) Antioxidant determinations by the use of a stable free radical. Nature, 181, 1199-1200

23. Re R, Pellegrini N, Proteggente A, Pannala A, Yang M, 
Rice-Evans C (1999) Antioxidant activity applying an improved ABTS radical cation decolorization assay. Free Radical Biol Med, 26, 1231-1237

24. Soh HS, Kim CS, Lee SP (2003) A new in vitro assay of cholesterol adsorption by food and microbial polysaccharides. J Med Food, 6, 225-230

25. Cushman DW, Cheung HS (1971) Spectrophotometic assay and properties of the angiotensin-converting enzyme of rabbit lung. Biochem Pharmacol, 20, 1637-1648

26. Yang YR, Park YK (2011) Comparison of antioxidant activities of black onion extracts. Korean J Food Preserv, 18, 954-960

27. Lee SJ, Shin JH, Kang MJ, Jung WJ, Ryu JH, Kim RJ, Sung NJ (2010) Antioxidants activity of aged red garlic. J Life Sci, 20, 775-781

28. Kim SB, Do JR, Lee YW, Gu YS, Kim CN, Park YH (1990) Nitrite-scavenging effects of roasted-barley extracts according to processing conditions. Korean $\mathbf{J}$ Food Sci Technol, 22, 748-752

29. Hong HD, Kim YC, Rho JH, Kim KT, Lee YC (2007) Changes on physicochemical properties of Panax ginseng C. A. Meyer during repeated steaming process. J Ginseng Res, 31, 222-229

30. Park CK, Jeon BS, Yang JW (2003) The chemical components of Korean ginseng. Food Industry and Nutrition, 8, 10-23

31. Yoon SR (2010) Optimization of heat processing conditions for improving the functional components and physiological properties of ginseng (Panax ginseng $\mathrm{C}$. A. Meyer). Ph D Thesis, Kyungpook National University, Korea, p 19-25

32. Ferruzzi MG, Bohm V, Courtney PD, Schwartz SJ (2002) Antioxidant and antimutagenic activity of dietary chlorophyll derivatives determined by radical scavenging and bacterial reverse mutagenesis assays. J Food Sci, 67, 2589-2595

33. Koca N, Karadeniz F, Burdurlu HS (2007) Effect of pH on chlorophyll degradation and colour loss in blanched green peas. Food Chem, 100, 609-615

34. Park SJ, Joung YM, Choi MK, Kim YK, Kim JG, Kim $\mathrm{KH}$, Kang MH (2008) Chemical properties of barley leaf using different drying methods. J Korean Soc Food Sci Nutr, 37, 60-65

35. Ryu SH, Lee HS, Lee YS, Kwon TW, Song YS, Moon GS (2005) Effect of $\beta$-carotene and vitamin $C$ on chlorophyll-induced photooxidation. J Korean Soc Food
Sci Nutr, 34, 99-106

36. Teng SS, Chen BH (1999) Formation of pyrochlorophylls and their derivatives in spinach leaves during heating. Food Chem, 65, 367-373

37. Kaewsuksaeng S, Tatmala N, Srilaong V, Pongprasert N (2015) Postharvest heat treatment delays chlorophyll degradation and maintains quality in Thai lime (Citrus aurantifolia Swingle cv. Paan). Postharvest Biol Technol, $100,1-7$

38. Choi WY, Lee CG, Seo YC, Song CH, Lim HW, Lee HY (2012) Effect of high pressure and steaming extraction processes on ginsenosides $\mathrm{Rg} 3$ and $\mathrm{Rh} 2$ contents of cultures-root in wild ginseng (Panax ginseng C. A. Meyer). Korean J Medicinal Crop Sci, 20, 270-276

39. Kang KS, Kim HY, Yamabe N, Yokozawa T (2006) Stereospecificity in hydroxyl radical scavenging activities of four ginsenosides produced by heat processing. Bioorg Med Chem Lett, 16, 5028-5031

40. Jin Y, Kim YJ, Jeon JN, Wang C, Min JW, Jung SY, Yang DC (2012) Changes of ginsenosides and physiochemical properties in ginseng by new 9 repetitive steaming and drying process. Korean J Plant Res, 25, 473-481

41. Velioglu YS, Mazza G, Gao L, Oomah BD (1998) Antioxidant activity and total phenolics in selected fruits, vegetables, and grain products. J Agric Food Chem, 46, 4113-4117

42. Yoshida T, Mori K, Hatano T, Okumura T, Uehara I, Komagoe K, OKUDA T (1989) Studies on inhibition mechanism of autoxidation by tannins and flavonoids. V. Radical-scavenging effects of tannins and related polyphenols on 1,1-diphenyl-2-picrylhydrazyl radical. Chem Pharm Bull, 37, 1919-1921

43. Shin JH, Kang JR, Kang MJ, Shin JH (2018) Physiological activity of five kinds of medicinal plant extracts with various solvents and their composites. J Life Sci, 28, 320-330

44. Song WY, Kim YN, Chun SS, Ku KH, Choi JH (2011) Effects of ethanol extracts from red pepper (Capsicum annuum L.) seeds on cholesterol adsorption capacity and UDP-glucuronyl transferase activity. J Life Sci, 21, 829-837

45. Yokozawa T, Kobayashi T, Oura H, Kawashima Y (1985) Studies on the mechanism of the hypoglycemic activity of ginsenoside- $\mathrm{Rb}_{2}$ in streptozotocin-diabetic rats. Chem Pharm Bull, 33, 869-872

46. Lee SD, Hwang WI, Okuda H (1996) Effect of acidic 
polysaccharide components of Korean ginseng on lipolytic action of toxohormone- $\mathrm{L}$ and on activity of angiotensin converting enzyme. J Ginseng Res, 20, 248-255
47. Hwang CR, Joung EM, Lee SH, Hwang IG, Kim YB, Jeong JH, Lee JS, Jeong HS (2013) Chemical components and enzyme activity of hydroponic-cultured ginseng roots and leaves under different heating temperatures. J Korean Soc Food Sci Nutr, 42, 911-916 